\title{
sciendo
}

RESEARCH PAPERS FACULTY OF MATERIALS

SCIENCE AND TECHNOLOGY IN TRNAVA

SLOVAK UNIVERSITY OF TECHNOLOGY

IN BRATISLAVA

2019, Volume 27, Number 44

DOI 10.2478/rput-2019-0009

\section{DETERMINATION OF FIRE RISK OF SELECTED ALCOHOLS}

\author{
Denis BENKO ${ }^{1}$, Jozef MARTINKA ${ }^{1}$, Tomáš ŠTEFKO ${ }^{1}$, \\ Igor WACHTER ${ }^{1}$, Peter RANTUCH ${ }^{1}$ \\ ${ }^{1}$ SLOVAK UNIVERSITY OF TECHNOLOGY IN BRATISLAVA, \\ FACULTY OF MATERIALS SCIENCE AND TECHNOLOGY IN TRNAVA, \\ INSTITUTE OF INTEGRAL SAFETY \\ UliCA JÁnA BotTu 2781/25, 91724 TRNAVA, SLOVAKIA \\ e-mail:denis.benko@stuba.sk, jozef.martinka@stuba.sk, tomas.stefko@stuba.sk, \\ igor.wachter@stuba.sk,peter.rantuch@stuba.sk \\ Received: 06.05.2019, Accepted: 11.06.2019, Published: 25.07.2019
}

\begin{abstract}
The aim of the research was to determine the fire risk of selected flammable liquids (alcohols). Four alcohols, methanol, ethanol, propanol, and butanol, were chosen for the research. Flammable liquids were examined in a cone calorimeter at 0 and $5 \mathrm{kW.m} \mathrm{m}^{-2}$ heat fluxes. Both, the cone calorimeter and test procedure, were in accordance with ISO 56601:2015. The fire risk was evaluated mainly on the basis of heat release rate, effective heat of combustion and carbon monoxide yield. Comparison of the achieved parameters of selected alcohols shows that the fire risk of the investigated alcohols increases with increasing the molar mass of alcohol and applied heat flow.
\end{abstract}

\section{Key words}

Fire risk, alcohols, cone calorimeter, heat release rate

\section{INTRODUCTION}

At present, lower alcohols (especially methanol, ethanol, propanol and butanol) are increasingly used in technical practice. Nevertheless, their fire risk has not been still comprehensively determined.

Heat Release Rate (HRR) is one of the most important fire characteristics. This parameter indicates the level of the fire risk and expresses flammability of the material it can also serve as an important tool in modelling the fire development and fire scenario simulations. In this regard, HRR is the key input for a wide range of the fire risk assessment tools, from simple risk indicators up to the complex CFD models (Computational Fluid Dynamics) as it affects virtually all other quantifiable fire-related variables [1].

An important advantage HRR is the fact that this characteristic feature does not only comprise the total amount of the heat released [J], but also expresses its time dependence during the fire development. Thus, the unit of HRR is joule per second $\left[\mathrm{Js}^{-1}\right]$, i.e. watt. Owing to the 
values commonly encountered in the real range of fire, kilowatts $[\mathrm{kW}]$ or megawatts $[\mathrm{MW}]$ are more frequently used [2].

Furthermore, the importance of this parameter is mainly reflected in the significant impact on living conditions at the site of the fire. It has been found that, when increasing the HRR, there is a time decrement for the development of unsustainable conditions, respectively the period of time during which the area affected by the fire is safe for human beings. All other fire characteristics or room descriptions have a lesser impact on this circumstance than HRR [2].

Equally important are the HRR values for designing a thermal load on the structure. Determination of the fire development in a fire compartment with subsequent detection of the temperature in the individual parts of the structure requires the knowledge of many parameters. The most important step is to design a fire scenario that best suits an emergency fire situation. Fire modelling based on physical parameters serves for this purpose [3]. These models are divided into [3]:

- Simplified: predominantly parametric fires, local fires, if flashover is unlikely;

- Improved: these models consider all major factors affecting a fire such as gas exchange, mass exchange and energy exchange. It is a single zone model, a two-zone model and computational dynamic models of liquids and gases.

The decisive factor is the change of HRR in time and determination whether the fire will develop into a flashover or whether it will only be a local fire. If there is no flashover, the fire will only run locally. In that case, a two-zone computational model can be used. The effects of local fire can be determined by a two-zone computational model or empirical models developed for fire of large fire sections [4]. That implies that, for fire modelling, it is of the utmost importance to know the most accurate input data to achieve an effective design of fire protection solutions for structures and buildings.

The aim of the paper is to determine the fire risk of lower alcohols (methanol, ethanol, propanol and butanol) based on the HRR, effective heat of combustion and carbon monoxide (CO) yield.

\section{MATERIALS AND METHODOLOGY OF EXPERIMENT}

$\mathrm{HRR}, \mathrm{CO}_{2}$ and $\mathrm{CO}$ yield and specific mass loss rate were determined on a cone calorimeter according to ISO 5660-1: 2015 based on a modified test procedure. The modification of the test procedure involved the use of a sample holder (different from the above ISO standard) which allowed the measurement of a liquid sample in a cone calorimeter. The liquid sample was poured into a cylindrical container with a diameter of $106 \mathrm{~mm}$ and a height of $15 \mathrm{~mm}$. The container diameter value was chosen to provide a sample surface area of $88.4 \mathrm{~cm}^{2}$ which is consistent with the requirements of ISO 5600-1: 2015 for solid materials, so that the results obtained could be comparable to those determined for solid materials. The container was made of steel sheet with a thickness of $1 \mathrm{~mm}$. This modification provided similar conditions to those found in a real fire. The air flow rate in the cone calorimeter was set to $24 \mathrm{l} \mathrm{s}^{-1}$ [5].

Alcohol samples were poured into a test tube of $106 \mathrm{~mm}$ diameter and $15 \mathrm{~mm}$ height. The sample was subsequently initiated by an electric spark with the prescribed initiating energy according to the standard (STN ISO 5660-1: 2015). The samples were burned at a heat flux of $0 \mathrm{~kW} \mathrm{~m}{ }^{-2}$ and $5 \mathrm{~kW} \mathrm{~m}^{-2}$.

\section{RESULTS AND DISCUSSION ON RESULTS}

Results of measurements are shown in Table 1. 


\begin{tabular}{|c|c|c|c|c|c|c|c|c|}
\hline \multirow[t]{2}{*}{ Parameter } & \multicolumn{8}{|c|}{ Measured values of individual samples } \\
\hline & $\begin{array}{l}\text { Methanol } \\
\text { 0 kW }\end{array}$ & $\begin{array}{l}\text { Ethanol } \\
0 \mathrm{~kW}\end{array}$ & $\begin{array}{l}\text { Propanol } \\
0 \mathrm{~kW}\end{array}$ & $\begin{array}{l}\text { Butanol } \\
0 \mathrm{~kW}\end{array}$ & $\begin{array}{l}\text { Methanol } \\
5 \mathrm{~kW}\end{array}$ & $\begin{array}{l}\text { Ethanol } \\
5 \mathrm{~kW}\end{array}$ & $\begin{array}{l}\text { Propanol } \\
5 \mathrm{~kW}\end{array}$ & $\begin{array}{l}\text { Butanol } \\
5 \mathrm{~kW}\end{array}$ \\
\hline \multicolumn{9}{|l|}{ Max. values } \\
\hline HRR $\left[\mathrm{kW} \mathrm{m}^{-2}\right]$ & 354.11 & 436.83 & 478.37 & 497.86 & 360.49 & 488.362 & 586.01 & 662.47 \\
\hline EHC $\left[\mathbf{M J ~ k g} \mathbf{~ k}^{-1}\right]$ & 34.91 & 65.89 & 58.28 & 71.98 & 48.81 & 62.26 & 78.54 & 78.62 \\
\hline $\operatorname{MLR}\left[\mathrm{g} \mathrm{s}^{-1}\right]$ & 0.18 & 0.18 & 0.16 & 0.19 & 0.19 & 0.21 & 0.20 & 0.20 \\
\hline SEA $\left[\mathrm{m}^{2} \mathrm{~kg}^{-1}\right]$ & 8.78 & 0 & 21.35 & 13.19 & 0.72 & 519.20 & 2532.44 & 70.15 \\
\hline $\mathrm{CO}\left[\mathrm{kg} \mathrm{kg}^{-1}\right]$ & 0.01 & 0.03 & 0.02 & 0.09 & 0.04 & 5.62 & 0.47 & 0.83 \\
\hline $\mathrm{CO}_{2}\left[\mathrm{~kg} \mathrm{~kg}^{-1}\right]$ & 6.07 & 10.79 & 7.94 & 22.01 & 3.99 & 3.84 & 3.82 & 3.14 \\
\hline \multicolumn{9}{|l|}{ Avg. values } \\
\hline HRR $\left[\mathrm{kW} \mathrm{m}^{-2}\right]$ & 239.90 & 323.22 & 363.95 & 381.88 & 292.84 & 233.65 & 358.04 & 350.39 \\
\hline EHC $\left[\mathrm{MJ} \mathrm{kg}^{-1}\right]$ & 19.91 & 27.60 & 31.67 & 34.34 & 19.71 & 27.16 & 31.51 & 33.62 \\
\hline $\operatorname{MLR}\left[\mathrm{g} \mathrm{s}^{-1}\right]$ & 0.10 & 0.10 & 0.10 & 0.09 & 0.13 & 0.07 & 0.10 & 0.09 \\
\hline SEA $\left[\mathrm{m}^{2} \mathbf{k g}^{-1}\right]$ & -9.12 & -12.24 & -9.11 & -4.88 & -8.05 & -11.71 & -7.30 & -5.84 \\
\hline $\mathrm{CO}\left[\mathrm{kg} \mathrm{kg}^{-1}\right]$ & 0.01 & 0.01 & 0.00 & 0.01 & 0.00 & 0.01 & 0.00 & 0.01 \\
\hline $\mathrm{CO}_{2}[\mathrm{~kg} \mathrm{kg-1]}$ & 1.18 & 1.65 & 1.89 & 2.03 & 1.19 & 1.66 & 1.91 & 2.09 \\
\hline $\begin{array}{l}\text { Total heat released } \\
{\left[\mathrm{MJ} \mathrm{m}^{-2}\right]}\end{array}$ & 176.40 & 244.26 & 285.70 & 311.47 & 174.31 & 241.38 & 284.80 & 306.76 \\
\hline $\begin{array}{l}\text { Total oxygen } \\
\text { consumption [g] }\end{array}$ & 110.15 & 153.00 & 178.97 & 19.98 & 110.33 & 153.50 & 181.36 & 196.04 \\
\hline Weight loss [g] & 78.24 & 78.37 & 79.73 & 80.20 & 77.99 & 78.39 & 79.82 & 80.61 \\
\hline $\begin{array}{l}\text { Avg. specific MLR } \\
{\left[\mathrm{g} \mathrm{s}^{-1} \cdot \mathrm{m}^{-2}\right]}\end{array}$ & 14.30 & 13.38 & 12.54 & 11.89 & 16.22 & 15.42 & 15.20 & 14.59 \\
\hline $\begin{array}{l}\text { Total } \quad \text { Smoke } \\
\text { production }\left[\mathbf{m}^{2} \mathbf{m}^{-2}\right]\end{array}$ & 0.51 & 0.03 & 0.12 & 6.89 & 0.04 & 2.68 & 1.62 & 1.54 \\
\hline $\begin{array}{l}\text { Total combustion } \\
\text { products }\left[\mathrm{m}^{2}\right]\end{array}$ & 0.00 & 0.00 & 0.00 & 0.06 & 0.00 & 0.02 & 0.01 & 0.02 \\
\hline MARHE $\left[\mathrm{kW} \mathrm{m^{-2 } ]}\right.$ & 265.13 & 346.85 & 336.43 & 247.46 & 302.87 & 389.67 & 439.26 & 450.12 \\
\hline
\end{tabular}

In the following figures (Figs.1 and 2), we can compare the evolution of HRR over time. We can also compare the influence of the number of carbons in the chain on these parameters, as well as the impact of heat flux on the measurement results.

Table 1 proved the impact of oxygen content in combustible liquid on its effective heat of combustion. This conclusion is in accordance with [6]. 


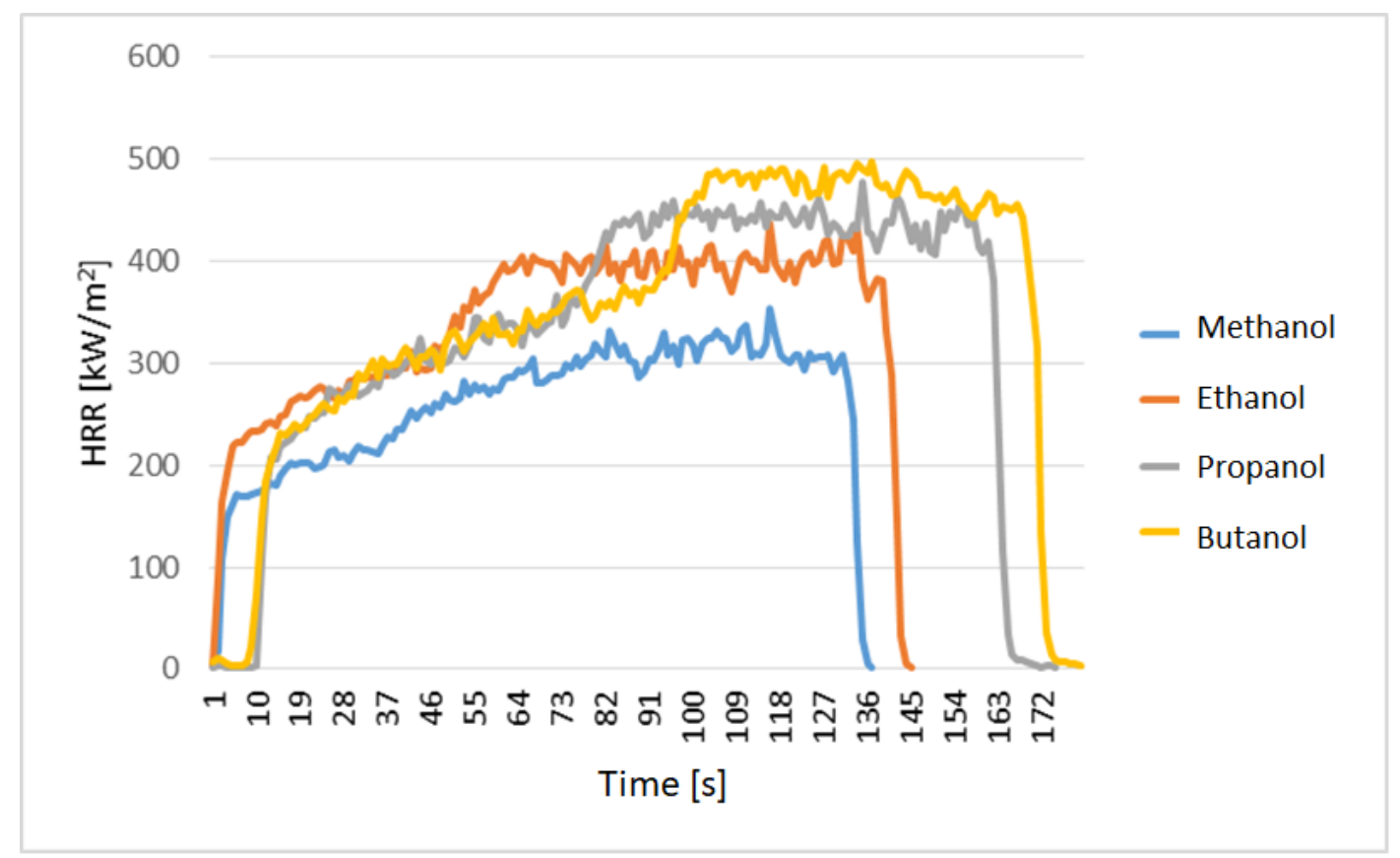

Fig. 1 Heat release rate of samples over time at heat flux $0 \mathrm{~kW} . \mathrm{m}^{-2}$

Heat release rate of the samples over time is shown in Fig.1. The Figure shows that butanol achieved the highest HRR, followed by propanol, ethanol, and finally methanol. Based on these curves, we can see that the number of carbons in the alcohol chain affects the HRR. We can also observe that the more carbons is in the chain, the longer its combustion process lasts. The measurement took place at a thermal flow of $0 \mathrm{~kW} \mathrm{~m}$.

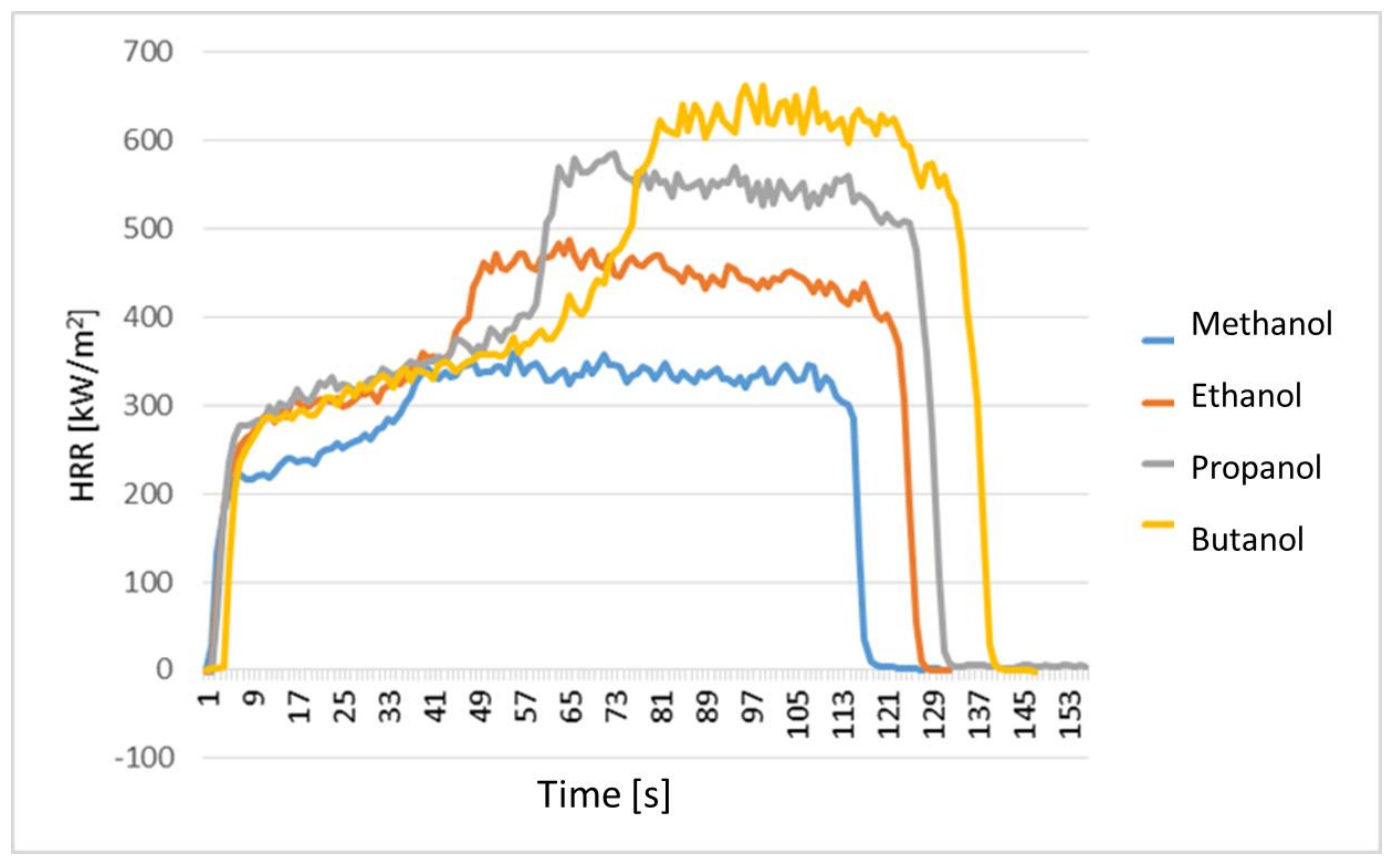

Fig. 2 Heat release rate of samples over time at heat flux $5 \mathrm{~kW} \mathrm{~m}^{-2}$

Fig. 2 shows, as in the previous case, the HRR over time, but at a thermal flux of $5 \mathrm{~kW} \mathrm{~m}^{-}$ ${ }^{2}$. In comparison with the previous results, we can observe that the heat flow affects the course of HRR. All samples reached higher maximum HRR values. The difference in the HRR between individual alcohols has also increased. Also, the heat flux reduced the conbustion time of the alcohols. 
The data in Table 1 show that with increasing molecular weight of the tested alcohols, both the maximum and the average values of HRR, MLR, total smoke production and $\mathrm{CO}$ and $\mathrm{CO}_{2}$ yields increase. The reason for this trend is probably the effective heat of combustion of alcohols increasing with the increasing molecular weight. Table 1 also shows that both the maximum and the average values of HRR, MLR, smoke production and $\mathrm{CO}$ and $\mathrm{CO}_{2}$ yields increase with the increasing heat flux. The cause of this trend is the increasing rate of evaporation of the investigated alcohols with increasing heat flux.

\section{CONCLUSION}

Based on the measured values and their comparison, we can conclude that the methodology for measuring liquids using a cone calorimeter is suitable for measuring the properties and characteristics of flammable liquids. The data obtained showed that, with increasing number of carbons in the molecule (with increasing molecular weight of low alcohols: methanol, ethanol, propanol and butanol), as well as increasing heat flow, their fire risk increases (especially heat release rate, effective heat of combustion and carbon monoxide yield, but also other parameters).

\section{Acknowledgement}

This research output was supported by the Slovak Research and Development Agency under the contract No. APVV-16-0223. This paper was also supported by the Cultural and Education Agency of the Ministry of Education, Science, Research and Sport of the Slovak Republic (KEGA 030UMB-4/2017).

\section{References}

[1] NAJMANOVÁ, H., HEJTMÁNEK, P., ŠEVČÍK, L. 2015. Rychlost uvolňování tepla jako parametr pro hodnoceni chováni materiálů při požáru (Heat release rate as parameter for assessment of behaviour of material during fire) [online]. Available at: https://www.imaterialy.cz/rubriky/materialy/rychlost-uvolnovani-tepla-jako-parametr-prohodnoceni-chovani-materialu-pri-pozaru_42776.html [Download 07/01/2019].

[2] BABRAUSKAS, V., PEACOCK, R., D. 1992 Heat release rate: The single most important variable in fire hazard. Fire Safety Journal, 18(3), 255-272 [vid. 2019-05-02]. ISSN 0379-7112. Doi:10.1016/0379-7112(92)90019-9

[3] HOROVÁ, K., WALD, F. 2012. Tepelná a mechanická zatižení konstrukcí při požáru (Thermal and mechanical lead of structures during fire). [online]. 2012. Available at: https://www.tzbinfo.cz/pozarni-bezpecnost-staveb/8853-tepelna-a-mechanicka-zatizeni-konstrukci-pri-pozaru [Download 07/01/2019].

[4] EUROPEAN COMMISION. Development of design rules for steel structures subjected to natural fires in large compartments. 1999. ISBN 92-828-7168-1.

[5] MARTINKA, J., CHREBET, T., BALOG, K. 2014. An assessment of petrol fire risk by oxygen consumption calorimetry. Journal of Thermal Analysis and Calorimetry, 117(1), 325-332. ISSN 1588-2926. Doi:10.1007/s10973-014-3686-6

[6] MARKOVÁ, I. 2008. Combustible liquids - characteristics and combustion description. In: Šenovský, M. ed. Fire Safety. Ostrava: SPBI. p. 334-348. ISBN 978-80-7385-040-1.

\section{ORCID}

$\begin{array}{ll}\text { Jozef Martinka } & 0000-0002-0060-5785 \\ \text { Tomás Stefko } & 0000-0002-3975-6775 \\ \text { Peter Rantuch } & 0000-0001-5826-8323 \\ \text { Igor Wachter } & 0000-0003-0691-0462\end{array}$

